\title{
Sources and Characteristics of Particulate Matter in Subway Tunnels in Seoul, Korea
}

\author{
Yongil Lee ${ }^{1,2}$, Young-Chul Lee ${ }^{3}$, , Taesung Kim ${ }^{2}$, Jin Seok Choi ${ }^{4}$ and Duckshin Park ${ }^{1, *(D)}$ \\ 1 Korea Railroad Research Institute (KRRI), 176 Cheoldobakmulkwan-ro, Uiwang-si 16105, Korea; \\ freego83@krri.re.kr \\ 2 Mechanical Engineering, Sungkyunkwan University, 2066 Seobu-ro, Suwon-si 16419, Korea; tkim@skku.edu \\ 3 Department of BioNano Technology, Gachon University, 1342 seongnamdae-ro, Seongnam-si 13120, Korea; \\ dreamdbs@gachon.ac.kr \\ 4 Analysis Center for Research Advancement, Korea Advanced Institute of Science and Technology (KAIST), \\ 291 Daehak-ro, Yuseong-gu, Daejeon-si 34141, Korea; ffband@kaist.ac.kr \\ * Correspondence: dspark@krri.re.kr; Tel.: +82-31-460-5367
}

Received: 27 September 2018; Accepted: 31 October 2018; Published: 12 November 2018

\begin{abstract}
Hazards related to particulate matter (PM) in subway systems necessitate improvement of the air quality. As a first step toward establishing a management strategy, we assessed the physicochemical characteristics of PM in a subway system in Seoul, South Korea. The mean mass of $\mathrm{PM}_{10}$ and $\mathrm{PM}_{2.5}$ concentrations $(n=13)$ were $213.7 \pm 50.4$ and $78.4 \pm 8.8 \mu \mathrm{g} / \mathrm{m}^{3}$, with $86.0 \%$ and $85.9 \%$ of mass concentration. Chemical analysis using a thermal-optical elemental/organic carbon (EC-OC) analyzer, ion chromatography (IC), and inductively coupled plasma (ICP) spectroscopy indicated that the chemical components in the subway tunnel comprised $86.0 \%$ and $85.9 \%$ mass concentration of $\mathrm{PM}_{10}$ and $\mathrm{PM}_{2.5}$. Fe was the most abundant element in subway tunnels, accounting for higher proportions of PM, and was detected in PM with diameters $>94 \mathrm{~nm}$. Fe was present mostly as iron oxides, which were emitted from the wheel-rail-brake and pantograph-catenary wire interfaces. Copper particles were $96-150 \mathrm{~nm}$ in diameter and were likely emitted via catenary wire arc discharges. Furthermore, $\mathrm{X}$-ray diffraction analysis (XRD) showed that the PM in subway tunnels was composed of calcium carbonate $\left(\mathrm{CaCO}_{3}\right)$, quartz $\left(\mathrm{SiO}_{2}\right)$, and iron oxides (hematite $\left(\alpha-\mathrm{Fe}_{2} \mathrm{O}_{3}\right)$ and maghemite- $\left.\mathrm{C}\left(\gamma-\mathrm{Fe}_{2} \mathrm{O}_{3}\right)\right)$. Transmission electron microscopy images revealed that the PM in subway tunnels existed as agglomerates of iron oxide particle clusters a few nanometers in diameter, which were presumably generated at the aforementioned interfaces and subsequently attached onto other PM, enabling the growth of aggregates. Our results can help inform the management of PM sources from subway operation.
\end{abstract}

Keywords: characteristics; particulate matter; source identification; subway tunnel; air quality

\section{Introduction}

Subway systems relieve traffic congestion in metropolitan areas as an environmentally friendly means of transportation [1-5]; however, human exposure to air pollutants in subway systems is a concern [6]. Particulate matter (PM) exerts detrimental effects on health. In 2013, the specialized cancer agency of the World Health Organization (WHO), the International Agency for Research on Cancer (IARC), announced that it classified outdoor air pollution as carcinogenic to humans (Group 1) [7]. For instance, a $10 \mu \mathrm{g} / \mathrm{m}^{3}$ decrease in $\mathrm{PM}_{10}$ concentration resulted in an $8.36 \%$ drop in the all-cause mortality rate in Beijing, China [8], and the mortality risk estimated in a Dutch cohort study for $\mathrm{PM}_{2.5}$ was $6 \%$ per $10 \mu \mathrm{g} / \mathrm{m}^{3}$ for natural-cause mortality [9]. 
Moreover, when PM is inhaled by the respiratory tract, smaller-diameter PM can penetrate the lung (alveolus) [10]. PM in subway systems is more harmful than other sources, e.g., wood combustion, traffic (vehicles), and roadways, due to redox active iron on the surface of the subway particles [11,12]. Specifically, in the literature [13], magnetite $\left(\mathrm{Fe}_{3} \mathrm{O}_{4}\right)$ was observed in the human brain.

The Seoul Metro Company installed platform screen doors (PSDs) at all stations, a feature which is also being implemented in other nations. PSDs reduce the risk of accidents and increase the operation efficiency of heating, ventilation, and air-conditioning systems [14,15]. As the installation of PSDs results in the isolation of the platform from the tunnel, the PM level on the platform is significantly reduced [15]; however, the accumulation of PM in the subway tunnel worsens the air quality therein [16].

The PM in subway tunnels originates from operation of the subway, ventilation, and re-suspension of settled PM [2,16-19]. Many studies reported high levels of PM in subway tunnels and determined its chemical composition [6]. Metals are the major constituents of PM in subway tunnels [16,20-23], principally Fe [16,22-24]. According to previous field studies, wear PM with peak diameters of 100, 350, and 300-700 nm is emitted during mechanical braking [3]. In addition, wear PM with peak diameters of 6.98 and $165.5 \mathrm{~nm}$ is emitted from the wheel-rail interface during electrical braking [2]. This PM in subway tunnels could penetrate the subway cabin via heating, ventilation, and air-conditioning (HVAC) systems and outflow via the ventilation system in the tunnel into the city.

The secondary pollutants $\left(\mathrm{SO}_{4}{ }^{2-}, \mathrm{NO}_{3}{ }^{-}\right.$, and $\left.\mathrm{NH}_{4}{ }^{+}\right)$in $\mathrm{PM}$ are photochemically converted from gases and comprise $2.4 \%$ of $\mathrm{PM}_{10}$ and $3.7 \%$ of $\mathrm{PM}_{2.5}$. In particular, $\mathrm{SO}_{4}{ }^{2-}$ is generated by secondary chemical reactions in the atmosphere $[25,26]$, whereas $\mathrm{NO}_{3}{ }^{-}$is generated by combustion of fossil fuels [27]. When the subway service is inactive, a diesel motor car is operated to maintain the tunnel, and $\mathrm{NO}_{3}{ }^{-}$and $\mathrm{SO}_{4}{ }^{2-}$ are transported from the outdoor air through the ventilation system [2,16,28-32].

Information on the chemical properties and sources of PM in subway tunnels is needed to facilitate an effective management strategy and thereby improve the air quality. In this study, we characterized the PM in subway tunnels beneath Seoul, Korea.

\section{Materials and Methods}

\subsection{Study Area}

In 2016, the Seoul metropolitan subway transported 7.4 million passengers daily. The Seoul Metro Company operates subway lines 1 to 8 , and other companies operate line 9 , the airport line, and the Bundang line. Line 4 is connected to the Danggogeo station in Seoul and the Oido station in Ansan, Geyonggi-do, consisting of an overground and underground section. The underground section runs from Beomgye to Chongshin University station and from Sinyongsan to Ssangmun station. The subway tunnels in line 4 consist of natural and mechanical ventilation systems, as shown Figure 1 . When the mechanical ventilation system is not in operation, it can use natural ventilation.

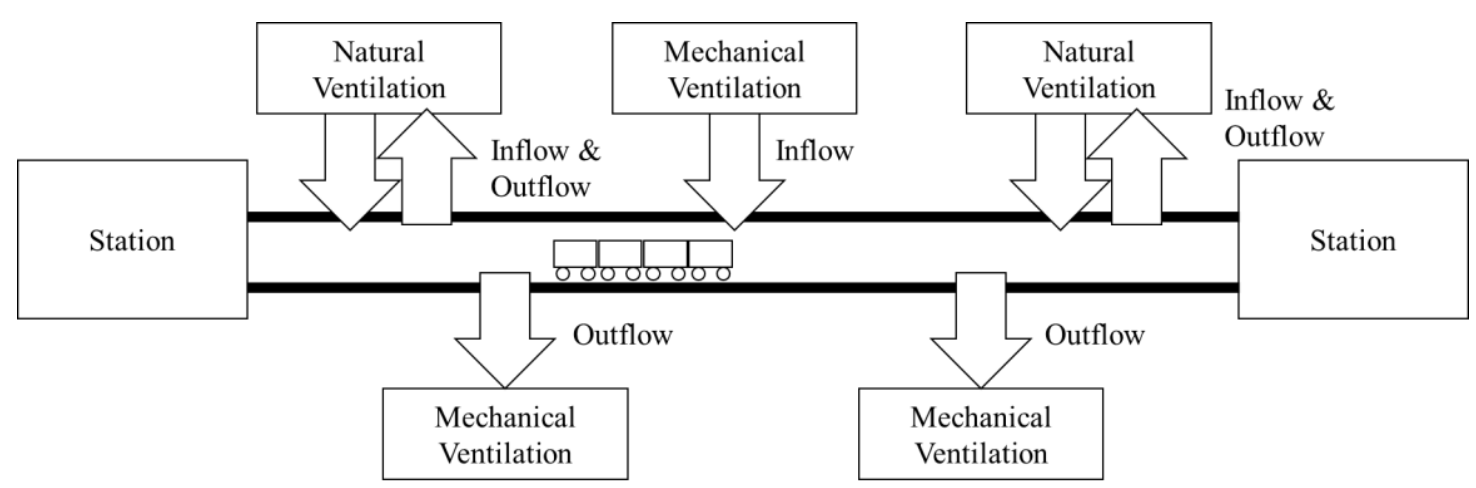

Figure 1. The natural and mechanical ventilation systems in line 4 . 
We analyzed the PM in a subway tunnel at the M station (60,000 passengers/day) and S station (27,000 passengers/day), which handle 490 trains per day with eight carriages (Figure 2). Figure 3 shows sampling positions on the platform equipped with PSDs.

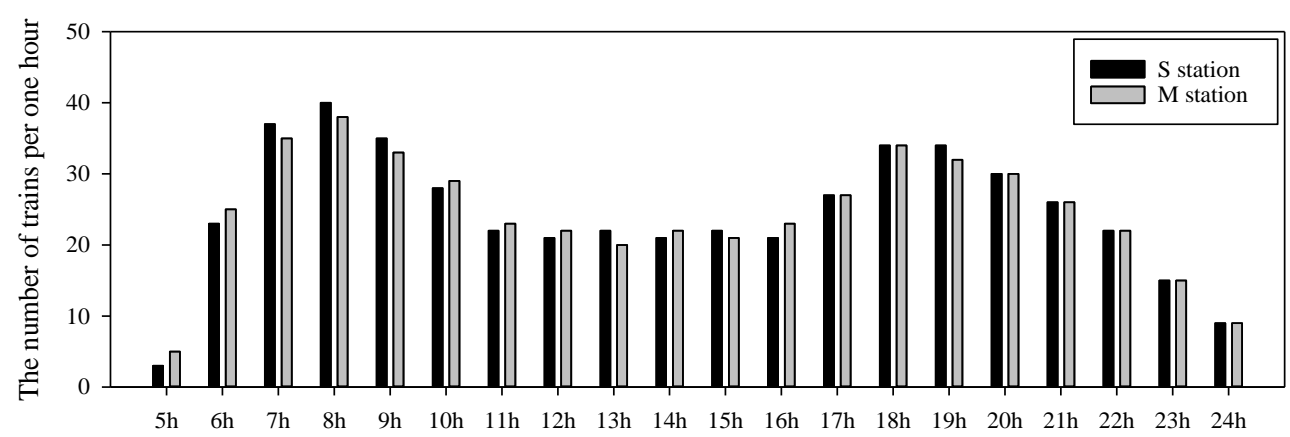

Figure 2. Number of trains at the M station and S station on weekdays.

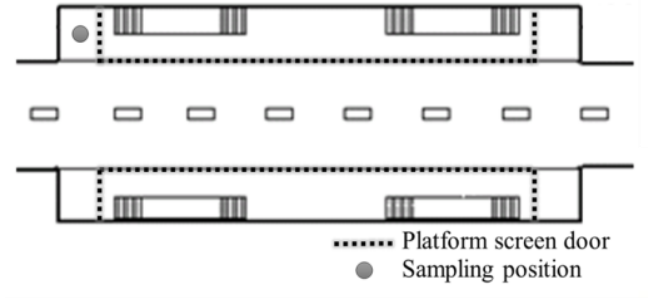

(A) M station

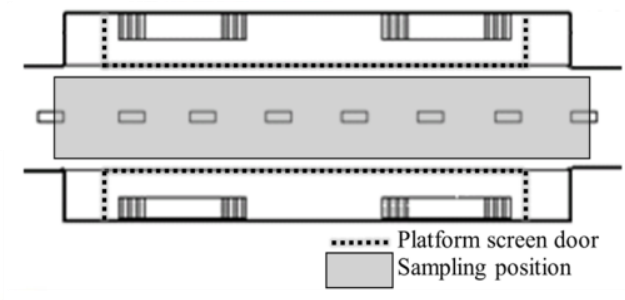

(B) S station

Figure 3. Positions of the sampling sites at the $M(\mathbf{A})$ and $S$ (B) stations.

\subsection{Collection and Analysis of Samples}

Table 1 lists the measurement devices and sampling periods. To analyze the inorganic, ionic, and carbonaceous components of PM, samples were collected in the subway tunnels at the M station from 15 May to 9 June 2017. PM samples were collected on quartz filters (QMA filter, $47 \mathrm{~mm}$ in diameter; Pall Corporation, New York, NY, USA) using a mini-volume air sampler (MiniVol TAS, $5 \mathrm{~L} / \mathrm{min}$; Airmetrics, Eugene, OR, USA) and Zefluor filters (polytetrafluoroethylene membrane filter, $47 \mathrm{~mm}$ in diameter; Pall Corporation, New York, NY, USA) using a low-volume air sampler (PMS-104, 16.7 L/min; APM, Bucheon, Korea). For the X-ray diffraction (XRD) analysis, samples were collected from the bottom of the subway tunnels at the $S$ station. The quartz and Zefluor filters were changed daily at 5:00 p.m. Lastly, for the transmission electron microscopy analysis, samples were collected in the subway tunnels on 18 April 2017.

To analyze the chemical composition and morphology of PM, an aluminum foil filter (CFG-225, $25 \mathrm{~mm}$ in diameter; Dekati, Kangasala, Finland) and electrical low-pressure impactor (ELPI, $10 \mathrm{~L} / \mathrm{min}$; Dekati, Kangasala, Finland) were used to collect PM samples from 15 May to 17 May 2017. The size distribution of PM was also stored in high-resolution ELPI+ mode (HR-ELPI+). The floor dust in the subway tunnels was collected and passed through a 1-mm (18 mesh) filter to identify crystalline material.

Zefluor filters were weighed before and after sampling using an analytical balance (sensitivity: $0.001 \mathrm{mg}$ ) after being equilibrated at constant temperature and humidity for three days in an electronic desiccator. Quartz filters were heated to $850{ }^{\circ} \mathrm{C}$ for $>2 \mathrm{~h}$ to remove organic matter before sampling.

After PM sampling, the Zefluor filters were cut in half using ceramic scissors. Each half was preprocessed for analysis of the inorganic and ionic components. Preprocessing for the inorganic component analysis was done using inductively coupled plasma (ICP) spectroscopy, and complied with the preprocessing standard of the Clean Water Act of the United States. The sample was placed in a perfluoroalkoxy polymer resin liner and mixed with $7 \mathrm{~mL}$ of $61 \%$ nitric acid and $3 \mathrm{~mL}$ of $35 \%$ hydrochloric acid. The mixture was then subjected to a pressure of $150 \mathrm{psi}$ for $10 \mathrm{~min}$ to extract 
inorganic components. The extracted solution was filtered (number $5 \mathrm{~B}$ filter paper, $110 \mathrm{~mm}$; Advance MFS), diluted with $50 \mathrm{~mL}$ of ultrapure water, and stored at $4{ }^{\circ} \mathrm{C}$ until required. The $\mathrm{Fe}, \mathrm{Ni}, \mathrm{Ba}, \mathrm{Pb}, \mathrm{V}$, $\mathrm{Cr}, \mathrm{Cu}, \mathrm{Zn}, \mathrm{Mn}$, and $\mathrm{Al}$ contents were analyzed using ICP atomic emission spectrometry (ICP-AES; ICPE-9000, Shimadzu, Japan).

Table 1. Measurement devices and sampling periods.

\begin{tabular}{|c|c|c|c|c|c|}
\hline Item & Filter & Particle Diameter & $\begin{array}{l}\text { Flow Rate } \\
\text { (L/min) }\end{array}$ & $\begin{array}{l}\text { Analysis } \\
\text { Instruments }\end{array}$ & $\begin{array}{c}\text { Sampling } \\
\text { Period and } \\
\text { Site }\end{array}$ \\
\hline $\begin{array}{l}\text { Low-volume } \\
\text { air sampler } \\
\text { (PMS-104) }\end{array}$ & Zefluor & $\mathrm{PM}_{10}$ and $\mathrm{PM}_{2.5}$ & 16.7 & $\begin{array}{l}\text { Ion compound } \\
\text { (IC), Metal } \\
\text { compound } \\
\text { (ICP-AES) }\end{array}$ & $\begin{array}{l}15 \text { May to } \\
9 \text { June } 2017 \\
\text { ( } n=13) \\
\text { M station, } \\
\text { Seoul }\end{array}$ \\
\hline $\begin{array}{l}\text { Mini-volume } \\
\text { air sampler } \\
\text { (MiniVol TAS) }\end{array}$ & Quartz & $\mathrm{PM}_{10}$ and $\mathrm{PM}_{2.5}$ & 5.0 & $\begin{array}{l}\text { Organic and } \\
\text { Elemental } \\
\text { Carbon } \\
\text { (Carbon } \\
\text { analyzer) }\end{array}$ & \\
\hline $\begin{array}{c}\text { Electrical } \\
\text { low-pressure } \\
\text { impactor } \\
\text { (ELPI) }\end{array}$ & Aluminum foil & $\begin{array}{c}14 \text { stages } \\
\left(\mathrm{D}_{50}{ }^{1}: 10,5.3,3.6\right. \\
2.5,1.6,0.94,0.60 \\
0.38,0.25,0.15 \\
0.094,0.054,0.030 \\
\text { and } 0.016 \mu \mathrm{m})\end{array}$ & 10.0 & $\begin{array}{l}\text { Morphology } \\
\text { and Chemical } \\
\text { by size } \\
\text { distribution }\end{array}$ & $\begin{array}{l}15 \text { May to } \\
17 \text { May } 2017 \\
\text { M station, } \\
\text { Seoul }\end{array}$ \\
\hline $\begin{array}{l}\text { Low-volume } \\
\text { air sampler } \\
\text { PMS-104 }\end{array}$ & Zefluor & $\mathrm{PM}_{10}$ & 16.7 & $\begin{array}{l}\text { (SEM and } \\
\text { TEM/EDX) }\end{array}$ & $\begin{array}{c}18 \text { April } 2018 \\
\text { S station, Seoul }\end{array}$ \\
\hline $\begin{array}{c}\text { Sieve } \\
(\text { mesh 18: } \\
\Phi=1.00 \mathrm{~mm})\end{array}$ & Zipper bag & $\begin{array}{l}\text { Floor dust under } 1 \\
\mathrm{~mm}\end{array}$ & - & $\begin{array}{l}\text { Chemical form } \\
\text { (XRD) }\end{array}$ & $\begin{array}{l}\text { Three times } \\
\text { within } 15 \text { May } \\
\text { to } 9 \text { June } 2017 \\
\text { S station, Seoul }\end{array}$ \\
\hline
\end{tabular}

For analysis of the water-soluble ion content, the filter paper was soaked in $20 \mathrm{~mL}$ of ultrapure water, and ions were extracted using an ultrasonic extractor. To prevent clogging of the ion chromatography (IC) column, the extracted solution was filtered through a $0.45-\mu \mathrm{m}$ SCA cellulose acetate syringe filter (CHMLAB Group, Barcelona, Spain); the filtered solution was stored in a 60-mL narrow-mouth bottle (Nalgene, Waltham, MA, USA) at $4{ }^{\circ} \mathrm{C}$. The water-soluble ion contents of the extracts were analyzed by IC (861 Advanced Compact IC; Metrohm, Herisau, Switherland). The $\mathrm{NO}_{3}{ }^{-}, \mathrm{SO}_{4}{ }^{2-}$, and $\mathrm{Cl}^{-}$anions were analyzed using MetroSep A Supp 5 and MetroSep RP 2 Guard columns, and the $\mathrm{NH}_{4}{ }^{+}, \mathrm{Na}^{+}, \mathrm{K}^{+}, \mathrm{Mg}^{2+}$, and $\mathrm{Ca}^{2+}$ cations were analyzed using MetroSep C 4 and $\mathrm{RP} 2$ guard columns.

A thermal-optical elemental/organic carbon (EC-OC) analyzer (Sunset Laboratory Inc., Parsippany, NJ, USA) was used to determine the organic carbon (OC) and elemental carbon (EC) contents following a thermal/optical transmittance (TOT) protocol [33]. The sample was heated to $900{ }^{\circ} \mathrm{C}$ in five steps in an He atmosphere to volatilize the OC and EC (Table 2). To evolve the EC and pyrolyzed OC, which were removed in the second part of the analysis, the sample was first cooled to $550{ }^{\circ} \mathrm{C}$ and heated in $2 \% \mathrm{O}_{2} / 98 \% \mathrm{He}$ to $910{ }^{\circ} \mathrm{C}$ in five steps. The analyzer utilizes laser transmission to correct for OC charring. The EC was determined as the $\mathrm{C}$ evolved after filter transmittance returned to the initial value. 
Table 2. NIOSH Method 5040 parameters.

\begin{tabular}{|c|c|c|c|c|}
\hline Program Activity & Carbon & Carrier Gas & Ramp Time (s) & $\begin{array}{c}\text { Program } \\
\text { Temperature }\left({ }^{\circ} \mathrm{C}\right)\end{array}$ \\
\hline Oven purge & - & \multirow{6}{*}{$\mathrm{He}$} & 10 & Ambient \\
\hline 1st ramp & OC1 & & 60 & 315 \\
\hline 2nd ramp & OC2 & & 60 & 475 \\
\hline 3rd ramp & OC3 & & 60 & 615 \\
\hline 4th ramp & OC4 and CC & & 90 & 870 \\
\hline Cooling for EC & $\mathrm{CC}$ & & 30 & 0 \\
\hline Stabilize temp & PC and EC & \multirow{6}{*}{$\mathrm{He} / \mathrm{O}_{2}$} & 45 & 550 \\
\hline $\mathrm{He} / \mathrm{O}_{2} 1$ st $\mathrm{ramp}$ & PC and EC & & 45 & 625 \\
\hline 2nd ramp & \multirow{4}{*}{$\mathrm{EC}$} & & 45 & 700 \\
\hline 3rd ramp & & & 45 & 775 \\
\hline 4th ramp & & & 45 & 850 \\
\hline 5 th ramp & & & 120 & 910 \\
\hline $\begin{array}{l}\text { External standard, } \\
\text { calibration and } \\
\text { cool down }\end{array}$ & - & $\begin{array}{c}\text { Calibration gas } \\
\text { and } \mathrm{He} / \mathrm{O}_{2}\end{array}$ & 120 & 0 \\
\hline
\end{tabular}

OC—organic carbon; CC—carbonate carbon; PC—pyrolytic carbon; EC—elemental carbon.

PM morphology was characterized by scanning electron microscopy (SEM; S-4700; Hitachi, Tokyo, Japan) and transmission electron microscopy (TEM; Talos F200X; FEI, Hillsboro, OR, USA). Energy-dispersive spectroscopy (EDX) was used to analyze the chemical composition of PM. PM samples on grids were sputter-coated with Pt prior to SEM. For TEM and EDX analysis, the filters were placed in tubes, mixed with $20 \mathrm{~mL}$ of deionized water, dispersed using an ultrasonic extractor, and transferred to a TEM grid (CF200 Cu-C film, 200 mesh; EMS, Hatfield, PA, USA) using a pipette.

For the XRD analysis (SmartLab; Rigaku, Austin, TX, USA), a 1-mm sieve was used to filter dust collected from the floor of subway tunnels.

Quality assurance of the ICP-AES, IC, and C analyses was performed using standard solutions. Accuracy was checked by calculating the relative error, and precision was checked by calculating the relative standard deviations (RSDs) and coefficients of variation of triplicate determinations. For the $\mathrm{C}$ analysis, the RSDs were calculated by analyzing the same sample in triplicate, as no standards that enable OC and EC to be distinguished are available.

\subsection{Estimated Carbonate by Ion Balance}

Atmospheric PM consists of cations $\left(\mathrm{Na}^{+}, \mathrm{NH}_{4}{ }^{+}, \mathrm{K}^{+}, \mathrm{Mg}^{2+}\right.$, and $\left.\mathrm{Ca}^{2+}\right)$, anions $\left(\mathrm{CO}_{3}{ }^{2-}, \mathrm{Cl}^{-}, \mathrm{NO}_{3}{ }^{-}\right.$, and $\mathrm{SO}_{4}{ }^{2-}$ ), and trace amounts of organic acids and metal cations. We used the ion balance to evaluate the acid-base balance. We were unable to evaluate the carbonate contents of PM by IC. Therefore, we estimated the carbonate contents of PM as the difference between the contents of all other anions and cations, as shown in Equation (1) [34].

$$
\mathrm{CO}_{3}{ }^{2-}=\left(\mathrm{Na}^{+}+\mathrm{NH}_{4}^{+}+\mathrm{K}^{+}+\mathrm{Mg}^{2+}+\mathrm{Ca}^{2+}\right)-\left(\mathrm{Cl}^{-}+\mathrm{NO}_{3}{ }^{-}+\mathrm{SO}_{4}{ }^{2-}\right) .
$$

The normal concentration of carbonate estimated by ion balance was converted into mass concentration, and the carbonate carbon (CC) concentrations were subtracted from the organic carbon $(\mathrm{OC})$ concentrations to avoid overlap with the carbonate estimated from the ion balance in Equation (1) [29]. 


\section{Results and Discussion}

\subsection{PM Mass}

In Seoul, air-quality monitoring stations (AQMS) are operated at 25 points, and their data are open-access. Thus, for the comparison of mass concentration outdoors and in subway tunnels, we collected $\mathrm{PM}_{10}$ and $\mathrm{PM}_{2.5}$ from the AQMS nearest to the $\mathrm{M}$ station during the measurement period.

The mean masses of $\mathrm{PM}_{10}$ and $\mathrm{PM}_{2.5}$ concentrations $(n=13)$ were $213.7 \pm 50.4$ and $78.4 \pm 8.8 \mu \mathrm{g} / \mathrm{m}^{3}$ in the subway tunnels and $44.0 \pm 13.9$ and $22.2 \pm 9.5 \mu \mathrm{g} / \mathrm{m}^{3}$ in outdoor air at the AQMS $(n=13)$, respectively (Figure 4$)$. The mass concentrations of $\mathrm{PM}_{10}$ and $\mathrm{PM}_{2.5}$ in the subway tunnel were 4.8- and 2.5-fold greater than their counterparts in outdoor air. The PM levels in the subway tunnels exceeded the WHO air-quality guidelines $\left(\mathrm{PM}_{10}, 24 \mathrm{~h}, 50 \mu \mathrm{g} / \mathrm{m}^{3} ; \mathrm{PM}_{2.5}, 24 \mathrm{~h}, 25 \mu \mathrm{g} / \mathrm{m}^{3}\right)$ [35]. In the subway tunnels, the $\mathrm{PM}_{10}$ mass concentration was 2.5-fold greater than that of $\mathrm{PM}_{2.5}$. As shown in Figure 4, the concentration in the subway tunnel increased as the concentration outdoors increased. For comparisons between the tunnel and outdoor concentrations of PM, an independent $t$-test was used according to the data distribution with the SPSS 24 software (IBM Corporation, New York, NY, USA). The independent $t$-test resulted in $t$-values of 15.7 and 11.7 for $\mathrm{PM}_{10}$ and $\mathrm{PM}_{2.5}$, respectively, and $p$-values lower than 0.001 for both, indicating a highly significant difference between the subway tunnel and outdoors.
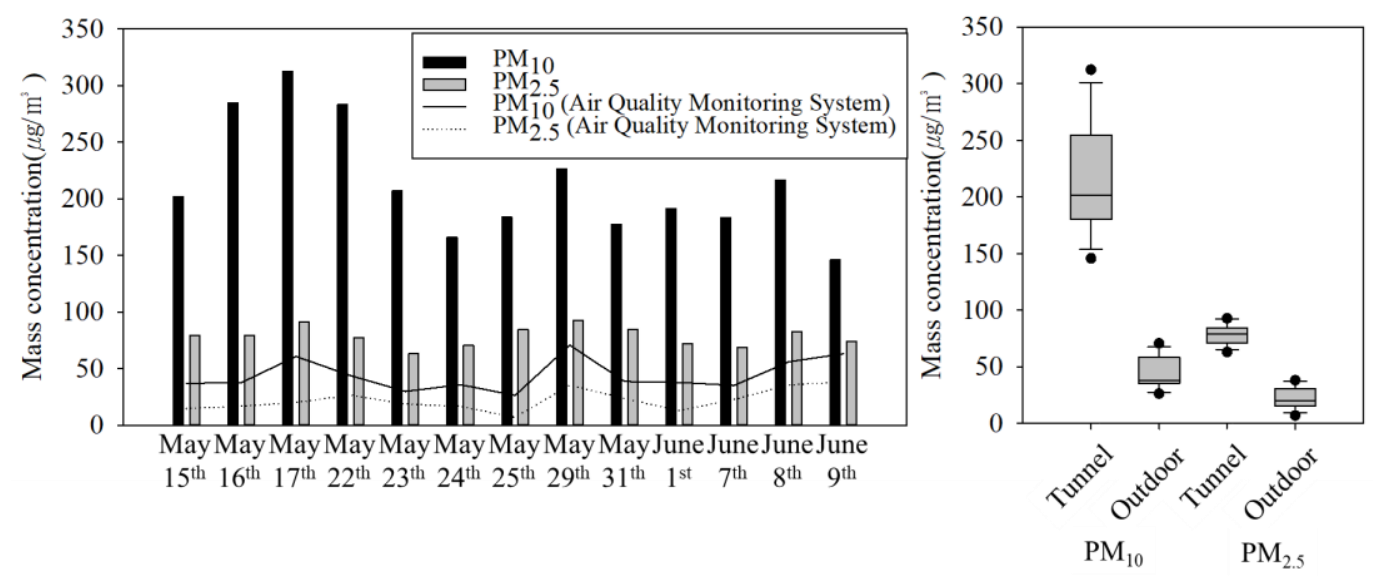

Figure 4. Particulate matter (PM) mass concentration in the subway tunnel at the M station.

$\mathrm{PM}_{10}$ originates from the wheel-rail-brake pad interface due to mechanical wear caused by the structural characteristics of the subway tunnels $[5,29,36]$. According to Park et al. [16], 67.7\% of $\mathrm{PM}_{10}$ originates from the wheel-rail-brake and catenary interfaces in subway tunnels. In addition, the PM concentration is influenced by train wind, the frequency of train operation, and tunnel cleaning [19]. The daily $\mathrm{PM}_{10}$ concentrations in the subway tunnel were quite different. As the measurement was only conducted on weekdays, it could be considered that the $\mathrm{PM}_{10}$ in the subway tunnel was diluted due to the operation of mechanical ventilation [37]. The $\mathrm{PM}_{10}$ concentrations in subway tunnels were reported to be $232-338 \mu \mathrm{g} / \mathrm{m}^{3}$ in Seoul and $51-470 \mu \mathrm{g} / \mathrm{m}^{3}$ in other countries [16,21,38-40]. For comparison, the mean $\mathrm{PM}_{10}$ mass concentration at the $\mathrm{M}$ station in 2014 was $184 \mu \mathrm{g} / \mathrm{m}^{3}$ [29], which is slightly lower than the finding in this study. The mechanical ventilation near the $\mathrm{M}$ station was improved in January 2017, and it could be considered to be the difference in cleanliness in the subway tunnels.

Figures 5 and 6 show the number, volume, and size distribution of PM in the subway tunnel at the $\mathrm{M}$ station between 7:00 and 8:00 p.m. on 15 May 2017. In the M station, a total of 36 trains stopped during that time. The number and volume of PM varied in a constant pattern. It is thought that the particles were generated from the subway and resuspended by the piston effect in the subway tunnels [19]. The volume in Figure 5A shows a similar pattern, as does the volume and number of PM in Figure 5B. However, the pattern of Figure 5A compared to Figure $5 \mathrm{~B}$ is different. This is due to the 
size distribution. The size distribution of the volume shows a bimodal shape with peaks at around 2-3 $\mu \mathrm{m}$ and $7-8 \mu \mathrm{m}$, while the number distribution shows a unimodal shape with a peak at around $0.02-0.03 \mu \mathrm{m}$.

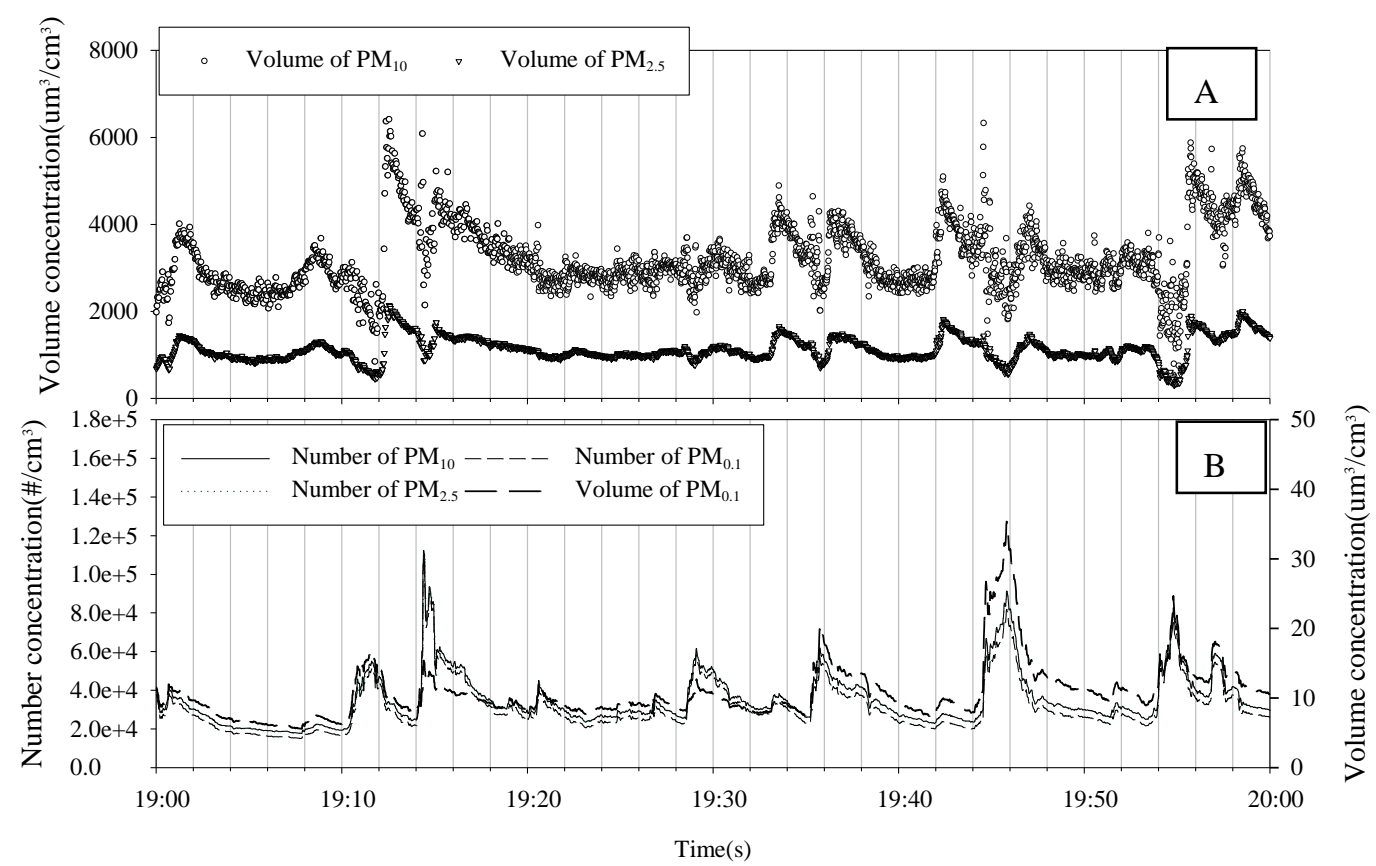

Figure 5. The number and volume of PM in the subway tunnel at the M station between 7:00 and 8:00 p.m. on 15 May 2017.

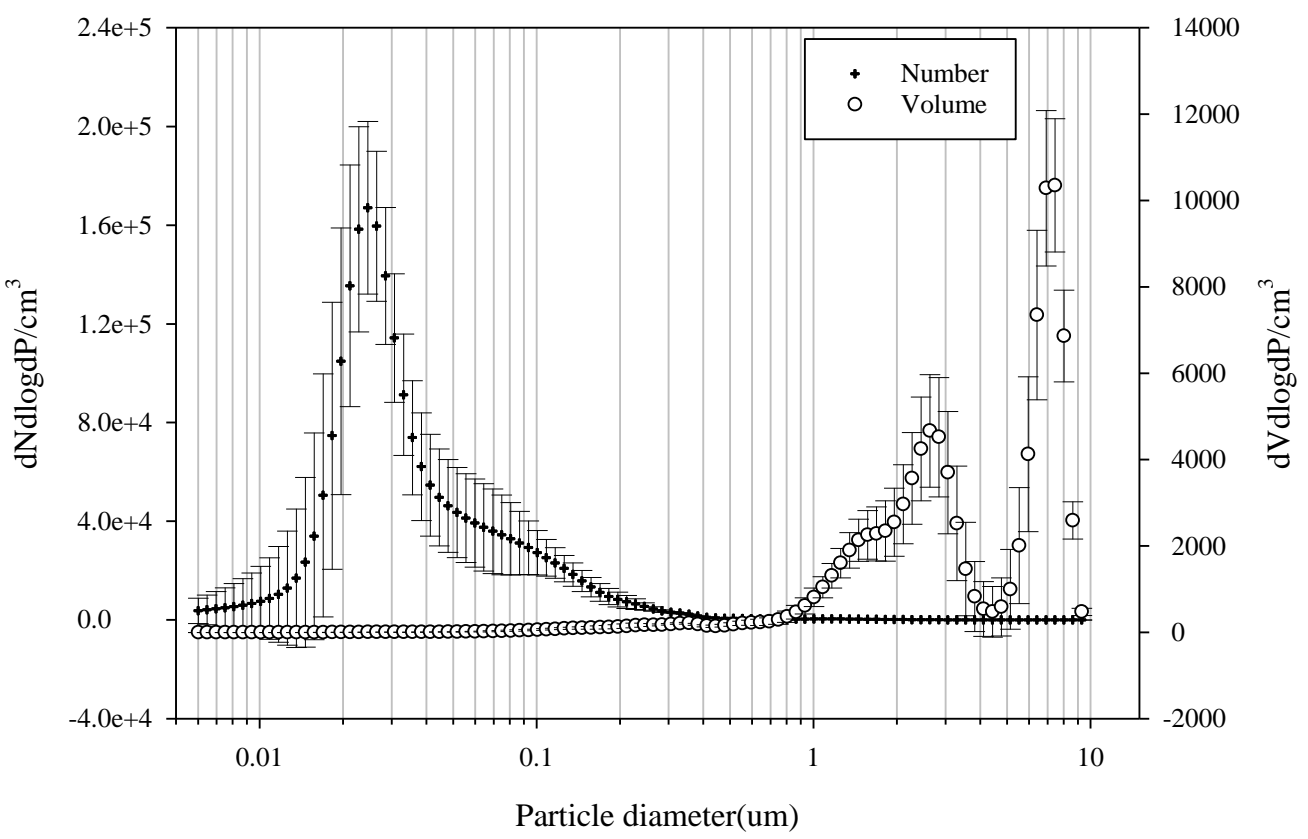

Figure 6. Size distribution of PM in the subway tunnel at the $M$ station between 7:00 and 8:00 p.m. on 15 May 2017.

\subsection{Chemical Composition of PM}

\subsubsection{Carbonaceous Compounds}

Figure 7 shows the mass concentrations of carbonaceous compounds in PM. The total carbon (TC) contents of $\mathrm{PM}_{10}$ and $\mathrm{PM}_{2.5}$ were $35.8 \pm 7.0$ (16.7\%) and $18.2 \pm 2.6 \mu \mathrm{g} / \mathrm{m}^{3}$ (23.2\%), respectively. 
Meanwhile, TC minus CC represented $16.1 \%$ of $\mathrm{PM}_{10}$ and $22.3 \%$ of $\mathrm{PM}_{2.5}$ (Table 3). These concentrations were higher than those of PM in outdoor air. The OC and EC concentrations of $\mathrm{PM}_{10}$ were $23.4 \pm 3.7$ and $11.1 \pm 3.8 \mu \mathrm{g} / \mathrm{m}^{3}$, and those of $\mathrm{PM}_{2.5}$ were $13.8 \pm 2.1$ and $3.8 \pm 0.8 \mu \mathrm{g} / \mathrm{m}^{3}$, respectively. CC comprised $1.3 \pm 0.6 \mu \mathrm{g} / \mathrm{m}^{3}$ of $\mathrm{PM}_{10}$ and $0.7 \pm 0.3 \mu \mathrm{g} / \mathrm{m}^{3}$ of $\mathrm{PM}_{2.5}$. However, it should be noted that the TOT method overestimates the OC content due to the mineral oxides (e.g., $\mathrm{Fe}_{2} \mathrm{O}_{3}$ and $\mathrm{SiO}_{2}$ ) present in the PM in subway tunnels [41]. Carbonate estimated using the ion balance comprised $3.1 \%$ of $\mathrm{PM}_{10}$ and $2.9 \%$ of $\mathrm{PM}_{2.5}$ [29,32]. In addition, $\mathrm{CaCO}_{3}$ and $\mathrm{SiO}_{2}$ were detected by XRD (Figure 8). The carbonaceous components of PM in subway tunnels originate from diesel PM emitted by the diesel motor car operated to maintain the tunnel $[16,20]$, as well as organic material transported from the outdoor air through the ventilation system [16,20], and the pantograph carbon strip-catenary wire interface $[4,42]$.
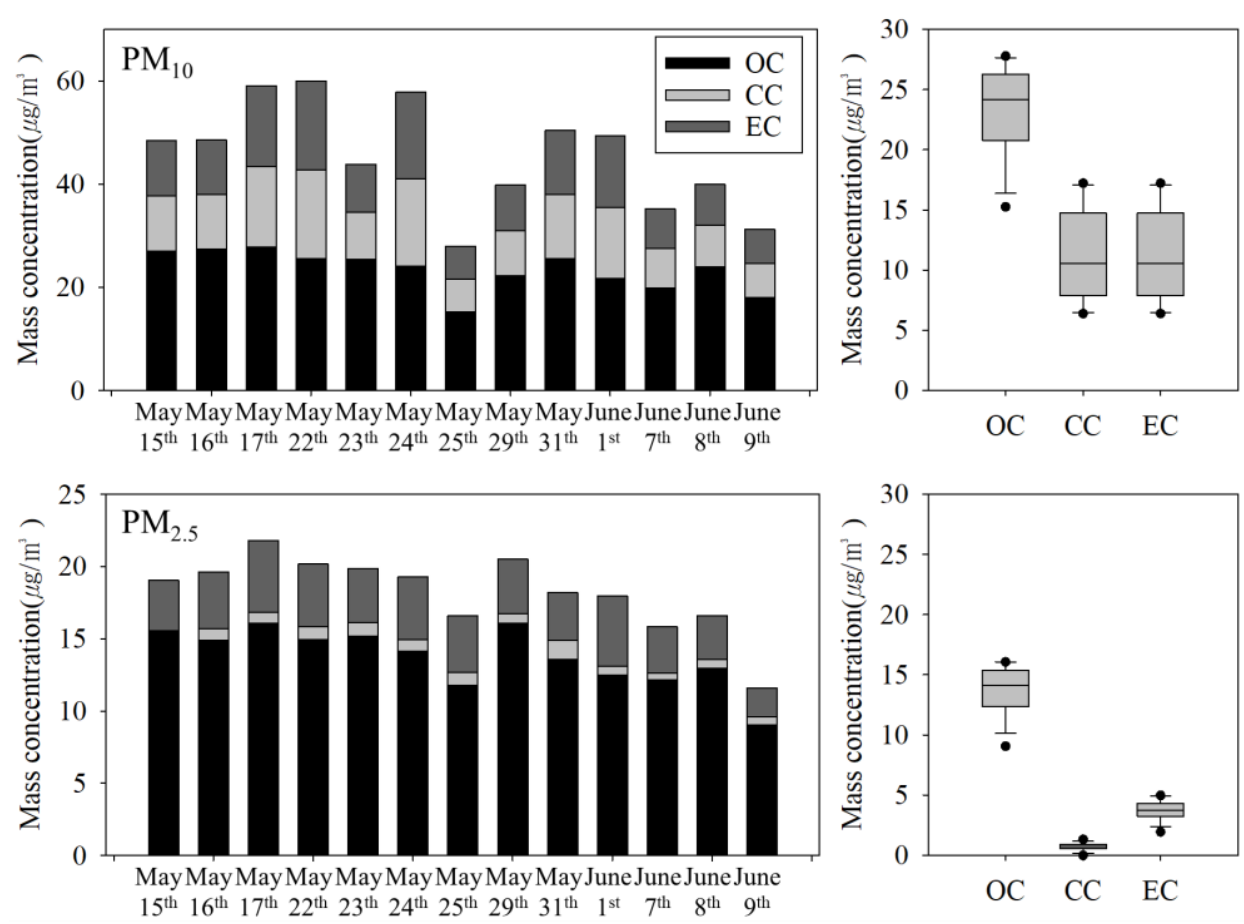

Figure 7. Mass concentrations of the carbonaceous components of PM in the subway tunnel at the M station $(n=13)$. OC—organic carbon; CC—carbonate carbon; EC-elemental carbon.

Table 3. Physical and chemical characteristics of PM at the M station $(n=13)$.

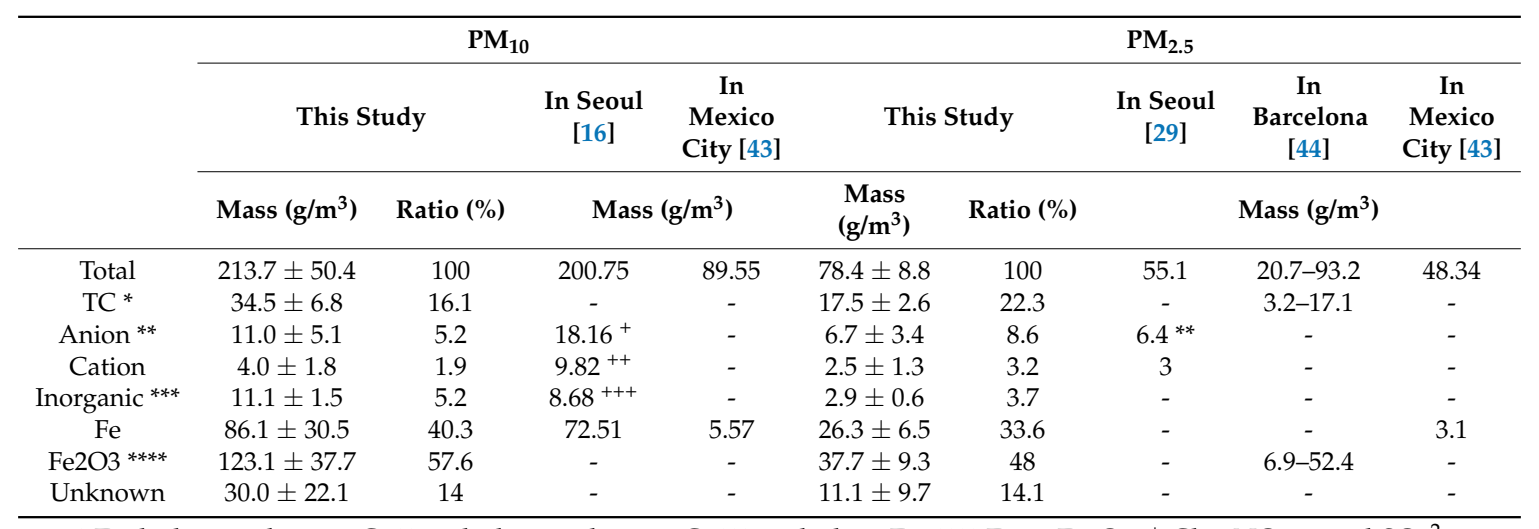

${ }^{*}$ Excluding carbonate $\mathrm{C}$; ${ }^{* *}$ including carbonate $\mathrm{C}$; ${ }^{* * *}$ excluding $\mathrm{Fe}$; ${ }^{* * *} \mathrm{Fe}$ as $\mathrm{Fe}_{2} \mathrm{O}_{3} ;{ }^{+} \mathrm{Cl}^{-}, \mathrm{NO}_{3}{ }^{-}$, and $\mathrm{SO}_{4}{ }^{2-}$;

${ }^{++} \mathrm{Na}^{+}, \mathrm{K}^{+}, \mathrm{Mg}^{2+}$, and $\mathrm{Ca}^{2+} ;{ }^{++} \mathrm{Al}, \mathrm{Ba}, \mathrm{Cr}, \mathrm{Cu}, \mathrm{Fe}, \mathrm{Mn}, \mathrm{Ni}, \mathrm{Pb}, \mathrm{Si}$, Ti, and $\mathrm{Zn}$. TC-total carbon. 


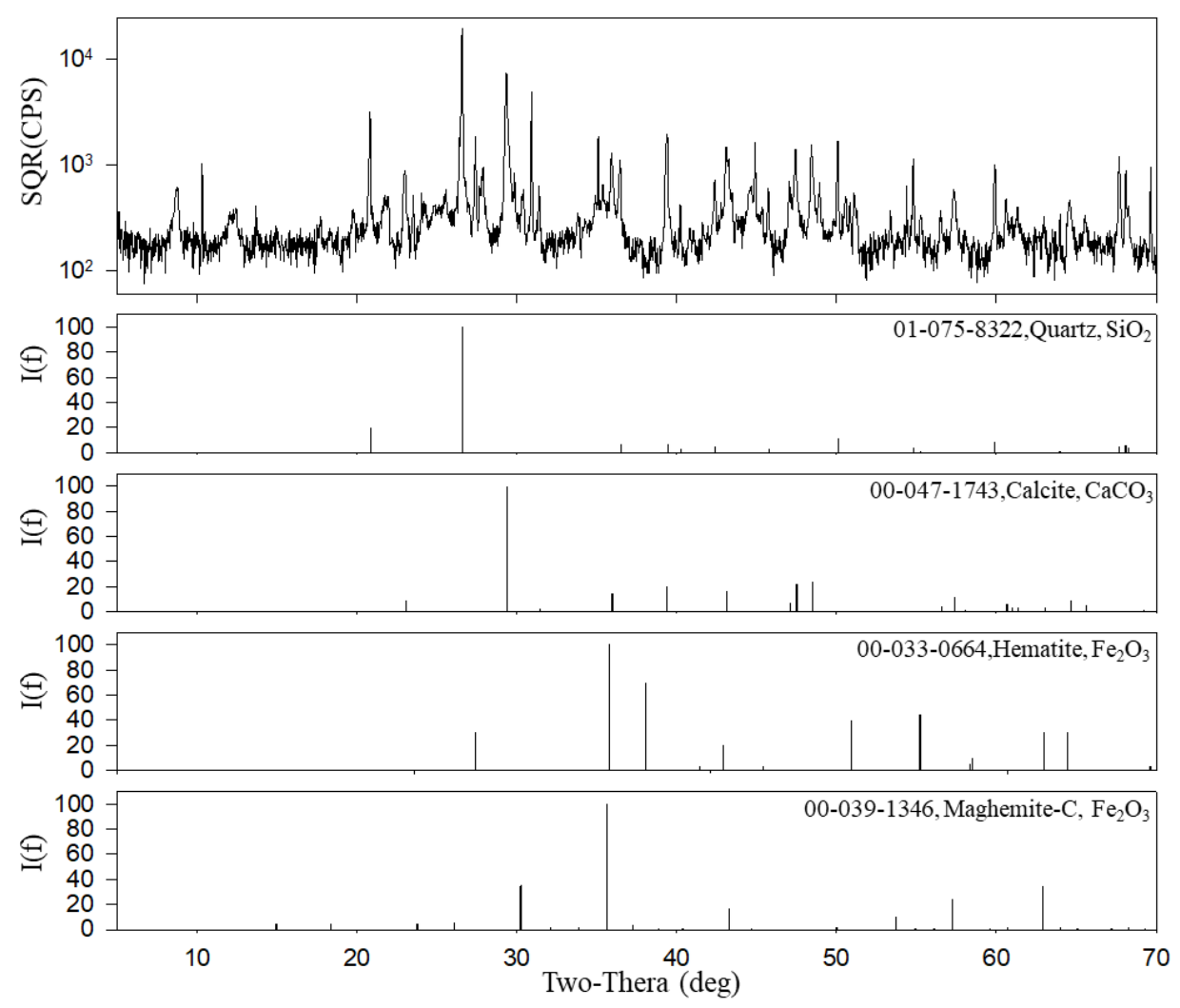

Figure 8. X-ray diffraction (XRD) patterns of PM in the subway tunnel at the $\mathrm{S}$ station.

\subsubsection{Ionic Compounds}

The mean mass concentrations of ionic compounds in $\mathrm{PM}_{10}$ and $\mathrm{PM}_{2.5}$ were $11.0 \pm 5.1$ and $6.7 \pm 3.4 \mu \mathrm{g} / \mathrm{m}^{3}$, respectively (Figure 9). The mean normal concentrations of anions (excluding $\mathrm{CO}_{3}{ }^{2-}$ ) and cations in $\mathrm{PM}_{10}$ were $0.09 \pm 0.05$ and $0.20 \pm 0.09 \mathrm{eq} / \mathrm{m}^{3}$, respectively, whereas those in $\mathrm{PM}_{2.5}$ were $0.05 \pm 0.04$ and $0.12 \pm 0.06 \mathrm{eq} / \mathrm{m}^{3}$, respectively. These results indicated that PM in the subway tunnels contained higher cation than anion (excluding $\mathrm{CO}_{3}{ }^{2-}$ ) contents. In this study, $\mathrm{CO}_{3}{ }^{2-}$ analysis was not conducted, and anions were lost from the filters because of the high temperature and humidity during sampling [45]. For this reason, we estimated the $\mathrm{CO}_{3}{ }^{2-}$ content based on the cation and anion equivalence [34].
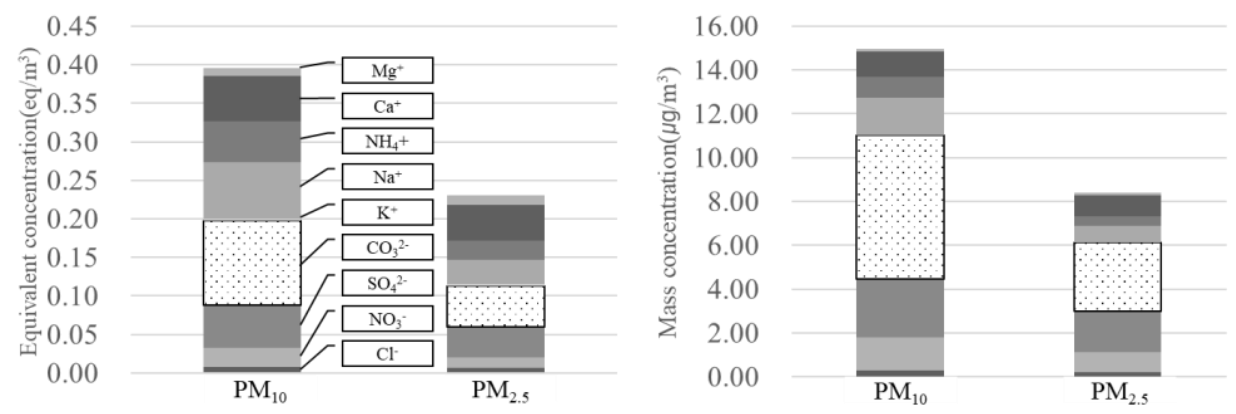

Figure 9. Normal and mass concentrations of ionic components in PM at the M station $(n=13)$.

The $\mathrm{CO}_{3}{ }^{2-}$ concentrations of $\mathrm{PM}_{10}$ and $\mathrm{PM}_{2.5}$ were $6.6 \pm 3.2$ and $4.5 \pm 1.5 \mu \mathrm{g} / \mathrm{m}^{3}$, respectively. The $\mathrm{CO}_{3}{ }^{2-}, \mathrm{SO}_{4}{ }^{2-}, \mathrm{Na}^{+}$, and $\mathrm{NO}_{3}{ }^{-}$concentrations in the Seoul subway system during the summer of 2010 were reported previously [29]. Subway tunnels are made of concrete, the debris of which accumulates on the tunnel floor. 


\subsubsection{Inorganic Compounds}

Inorganic compounds represented $47.0 \%$ of $\mathrm{PM}_{10}$ and $38.2 \%$ of $\mathrm{PM}_{2.5}$. Fe (principally iron oxides) comprised $40.3 \%$ of $\mathrm{PM}_{10}$ and $33.6 \%$ of $\mathrm{PM}_{2.5}$, which was higher than previously reported $(36.1 \%$ of $\left.\mathrm{PM}_{10}\right)$ [16].

The mass concentrations of $\mathrm{Fe}$ in $\mathrm{PM}_{10}$ and $\mathrm{PM}_{2.5}$ were $86.1 \pm 30.5$ and $26.3 \pm 6.5 \mu \mathrm{g} / \mathrm{m}^{3}$, respectively, whereas the mass concentrations of other inorganic compounds $(\mathrm{Ni}, \mathrm{Mn}, \mathrm{Ba}, \mathrm{Pd}, \mathrm{V}, \mathrm{Cr}$, $\mathrm{Cu}, \mathrm{Zn}$, and $\mathrm{Al}$ ranged from 0.63 to $1.65 \mu \mathrm{g} / \mathrm{m}^{3}$ in $\mathrm{PM}_{10}$ and 0.027 to $0.684 \mu \mathrm{g} / \mathrm{m}^{3}$ in $\mathrm{PM}_{2.5}$ (Figure 10). Indeed, nano-sized PM were reported to be emitted from the wheel-rail-brake interface $[2,5,46]$.
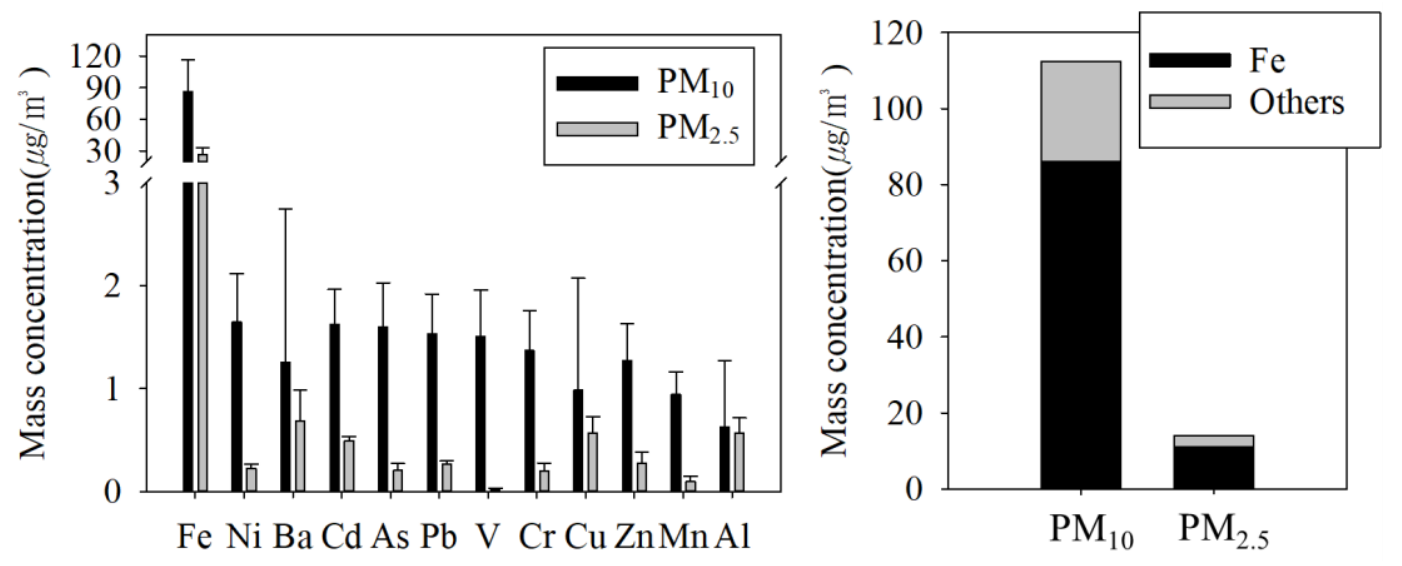

Figure 10. Mass concentrations of inorganic components in PM at the $\mathrm{M}$ station.

In addition to iron oxides in PM in the subway tunnel, we detected two iron oxides as hematite $\left(\alpha-\mathrm{Fe}_{2} \mathrm{O}_{3}\right)$ and maghemite- $\mathrm{C}\left(\gamma-\mathrm{Fe}_{2} \mathrm{O}_{3}\right)$ using XRD (Figure 8). $\mathrm{Fe}_{2} \mathrm{O}_{3}$ represented $57.6 \%$ of the $\mathrm{PM}_{10}$ and $48.0 \%$ of the $\mathrm{PM}_{2.5}$ in the subway tunnel. Fe in subway tunnels is present as iron oxides and mineral elements; e.g., $\mathrm{FeO}_{x} / \mathrm{SiO}_{2}$ [23]. The estimated mass of $\mathrm{Fe}_{2} \mathrm{O}_{3}$ was $123.1 \pm 37.7 \mu \mathrm{g} / \mathrm{m}^{3}$ in $\mathrm{PM}_{10}$ and $37.7 \pm 9.3 \mu \mathrm{g} / \mathrm{m}^{3}$ in $\mathrm{PM}_{2.5}$ (Table 3). In the case of European subway systems, $\mathrm{Fe}_{2} \mathrm{O}_{3}$ is the most abundant element on platforms without PSDs, accounting for 30-66\% of the total $\mathrm{PM}_{2.5}$, followed by carbonaceous components (18-37\%) [32,47]. Fe reportedly also predominates the subway systems of other cities [43,48-50].

Meanwhile, Ni, Mn, Ba, Pd, V, Cr, Cu, Zn, and Al together comprised 5.2\% of $\mathrm{PM}_{10}$ and $3.2 \%$ of $\mathrm{PM}_{2.5}$. Fe, $\mathrm{Ba}$, and $\mathrm{Mn}$ are used in the wheel-rail-brake system, and $\mathrm{Ni}, \mathrm{V}$, and $\mathrm{Cr}$ are included in lubricant and are generated by oil combustion [28]. The Fe/Mn ratio in $\mathrm{PM}_{10}$ was 99.7, which was similar to previous reports regarding rail, wheel, and electric sliding collectors (Fe:Mn ratio, 92-121) $[16,48,51-53]$. $\mathrm{Cu}$, the major component of catenary wire, comprised $0.98 \pm 1.09 \mu \mathrm{g} / \mathrm{m}^{3}$ of $\mathrm{PM}_{10}$ and $0.53 \pm 0.97 \mu \mathrm{g} / \mathrm{m}^{3}$ of $\mathrm{PM}_{2.5}$. The carbon strip-catenary wire interface undergoes wear, and a short circuit between the wire and the strip generates an arc discharge [54,55]; according to a previous study [16], electrical cable wear is estimated to contribute about $8.1 \%$ of $\mathrm{PM}_{10}$.

\subsection{Morphology and Energy-Dispersive Spectroscopy (EDX)}

We analyzed the morphology of PM in the subway tunnel (Figure 11). PM of 1- $\mu$ m diameter is considered to be abrasive PM generated by mechanical wear at the wheel-rail-brake interface $[24,56]$. The majority of dust particles with diameters of below $1 \mu \mathrm{m}$ PM displayed irregular spheres.

An SEM/EDX elemental map of $\mathrm{PM}_{2.5}$ is shown in Figure 12. Fe accounted for $44.14 \mathrm{wt} . \%$, followed by C ( $28.07 \mathrm{wt} . \%)$ and O (20.43 wt.\%). The Fe component was distributed evenly in the elemental map, suggesting that nano-sized Fe PM generated by friction was condensed with or attached to other PM [18].

Through EDX analysis, Fe was detected in PM $\geq 94 \mathrm{~nm}$ (Table 4). Studies showed that 100-200-nm nanoparticles are generated from the wheel-rail-brake interface $[2,18]$. The ratio of Fe increased with 
increasing particle size, reaching $47.2 \%$ for $1.6-\mu \mathrm{m}$-diameter PM. Ca and $\mathrm{Si}$ were detected in $380-\mathrm{nm}$ PM. Meanwhile, $\mathrm{S}$ was detected in $\mathrm{PM} \geq 30 \mathrm{~nm}$, with the highest proportion in 250-nm PM. S entered the subway tunnel from outside [29]. Cu was detected in PM between 94 and $150 \mathrm{~nm}$. To supply electricity, a catenary wire is attached to the pantograph; however, short circuits generate an arc discharge, resulting in the emission of $\mathrm{Cu}$ nanoparticles. $\mathrm{Cu}$ was also present as copper oxides, e.g., $\mathrm{CuO}$. Notably, $\mathrm{CuO}$ nanoparticles have greater toxicity than $\mathrm{CuO}$ microparticles [57]. Crustal PM ( $\mathrm{Ca}$ and $\mathrm{Si}) \geq 380 \mathrm{~nm}$ could have been generated due to the deterioration of subway facilities and the inflow of soil dust from outdoors. Ba (which is present in brake components) PM of 0.940-2.500 $\mu \mathrm{m}$ was also detected.

Table 4. Chemical composition of PM according to size at the M station (unit, \%).

\begin{tabular}{|c|c|c|c|c|c|c|c|c|c|c|c|c|}
\hline $\begin{array}{l}\text { Particle Size } \\
\qquad(\mu \mathrm{m})\end{array}$ & $C_{K}$ & $\mathbf{O}_{K}$ & $\mathbf{S}_{K}$ & $\mathrm{Fe}_{K}$ & $C \mathbf{u}_{\mathrm{L}}$ & Cа ${ }_{K}$ & $S i_{K}$ & $\mathrm{Ba}_{\mathrm{L}}$ & $\mathrm{Br}_{\mathrm{L}}$ & $\mathbf{K}_{\mathbf{K}}$ & $\operatorname{Mo}_{L}$ & $\mathbf{M g}_{\mathrm{K}}$ \\
\hline 0.016 & 91.58 & 7.21 & & & & & & & & & 1.21 & \\
\hline 0.030 & 84.81 & 12.25 & 2.94 & & & & & & & & & \\
\hline 0.054 & 95.65 & 4.35 & & & & & & & & & & \\
\hline 0.094 & 80.95 & 11.49 & 3.39 & 1.73 & 1.89 & & & & & 0.56 & & \\
\hline 0.150 & 83.17 & 8.62 & 1.48 & 1.45 & 1.87 & & & & 3.42 & & & \\
\hline 0.250 & 70.67 & 8.26 & 8.86 & 12.21 & & & & & & & & \\
\hline 0.380 & 64.03 & 17.95 & 1.55 & 14.80 & & 0.7 & 0.96 & & & & & \\
\hline 0.600 & 60.89 & 14.31 & 0.87 & 20.54 & & 1.32 & 1.27 & & 0.80 & & & \\
\hline 0.940 & 40.37 & 18.65 & 0.78 & 34.19 & & 2.06 & 1.83 & 2.11 & & & & \\
\hline 1.600 & 21.69 & 22.97 & 0.79 & 47.20 & & 2.38 & 3.09 & 1.87 & & & & \\
\hline 2.500 & 28.07 & 20.43 & 0.60 & 44.14 & & 1.95 & 2.73 & 1.64 & & & & 0.44 \\
\hline 3.600 & 38.62 & 18.28 & 0.76 & 37.96 & & 1.63 & 2.74 & & & & & \\
\hline
\end{tabular}

$\mathrm{K}, \mathrm{L}$ is principal quantum number of elemental.
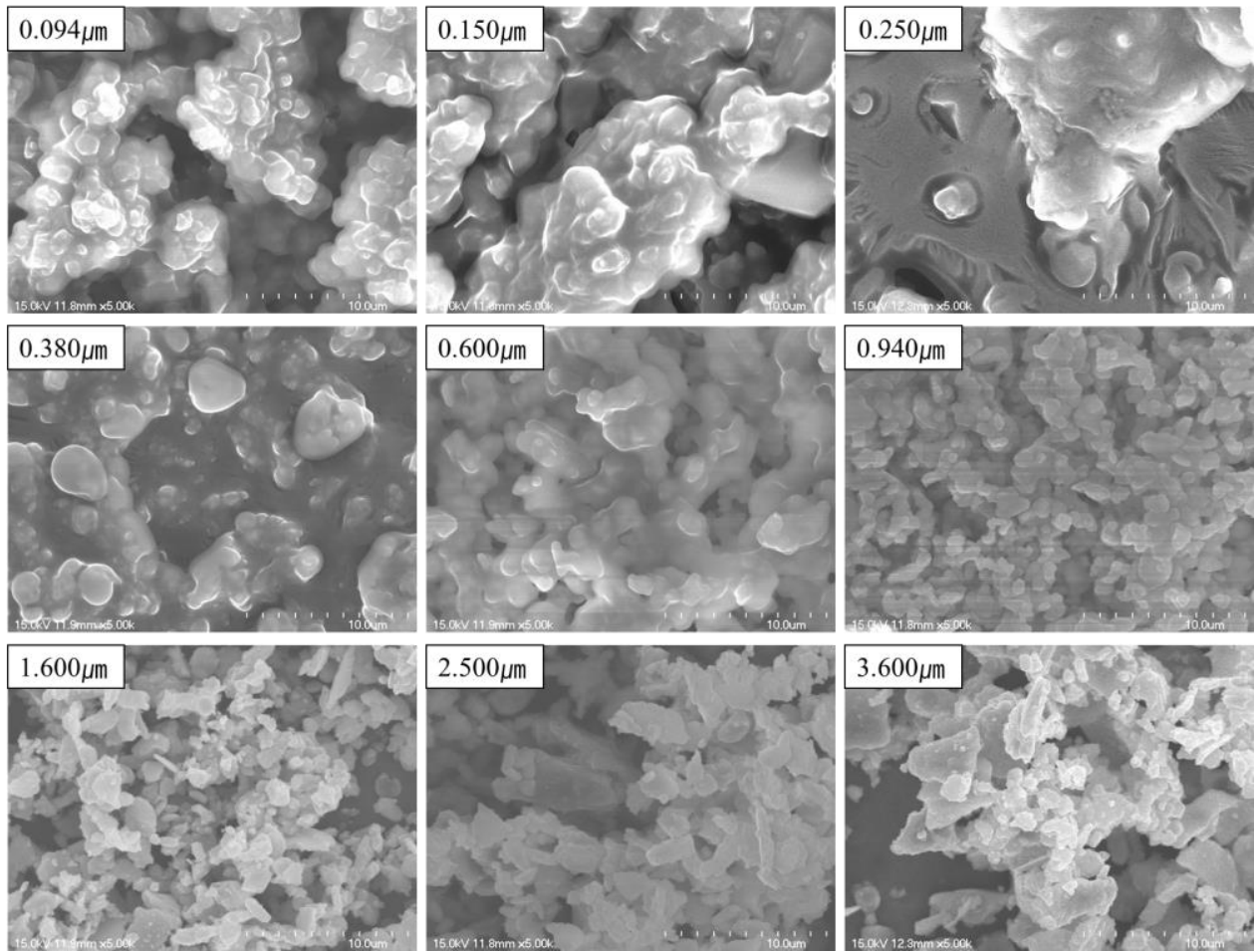

Figure 11. Morphology of PM in subway tunnels according to size at the M station. 

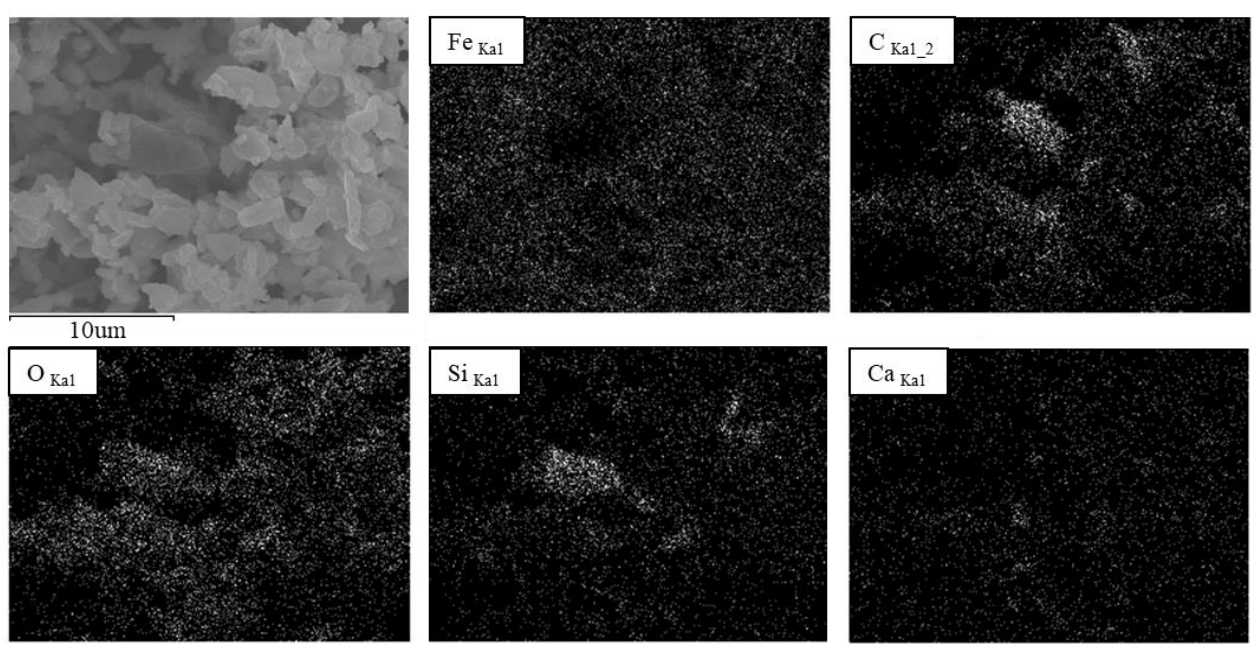

Figure 12. Elemental map of $\mathrm{PM}_{2.5}$ at the $\mathrm{M}$ station.

According to prior studies [2,18], nanoparticles are generated at sites of wheel-rail contact that surpass a given temperature threshold as the train brakes. It is assumed that nanoparticles were emitted at the wheel-rail contact rather than the brake pad-disc interface due to the difference in $\mathrm{Ba}$ and Fe particle size.

According to the XRD patterns (Figure 8), the PM in subway tunnels comprised calcium carbonate $\left(\mathrm{CaCO}_{3} ; \mathrm{JCPDS}\right.$ card number, 00-047-1743), quartz $\left(\mathrm{SiO}_{2} ; 01-075-8322\right)$, hematite $\left(\alpha-\mathrm{Fe}_{2} \mathrm{O}_{3} ; 00-033-0664\right)$, and maghemite- $\mathrm{C}\left(\gamma-\mathrm{Fe}_{2} \mathrm{O}_{3} ; 00-039-1346\right)$. Calcium carbonate is a major component of cement, and quartz is the second most abundant mineral in continental crust. Upon exposure to air, Fe is oxidized into iron oxide or iron hydroxide; the latter is reportedly present on the surface of rails in the Tokyo metro [58]. Previous studies reported the presence of calcium carbonate $\left(\mathrm{CaCO}_{3}\right)$, quartz $\left(\mathrm{SiO}_{2}\right)$, hematite $\left(\alpha-\mathrm{Fe}_{2} \mathrm{O}_{3}\right)$, maghemite $\left(\gamma, \varepsilon-\mathrm{Fe}_{2} \mathrm{O}_{3}\right)$, magnetite $\left(\mathrm{Fe}_{3} \mathrm{O}_{4}\right), \mathrm{Fe}$, goethite $(\alpha-\mathrm{FeOOH})$, and akaganeite $(\beta-\mathrm{FeOOH})$ in PM $[24,49,58-60]$. However, in this study, we did not detect Fe, goethite, akaganeite, or magnetite using XRD spectroscopy.

TEM images of PM in the subway tunnels showed flakes of iron oxide nanocrystals (Figure 13). According to previous reports and the XRD patterns, iron oxide PM contains various chemical species, e.g., hematite $\left(\alpha-\mathrm{Fe}_{2} \mathrm{O}_{3}\right)$, magnetite $\left(\mathrm{Fe}_{3} \mathrm{O}_{4}\right)$, and goethite $(\alpha-\mathrm{FeOOH})[23,58]$. The PM showed mottling of clusters of rounded ferruginous nanocrystals a few nanometers in width, along with highly crystalline magnetite, hematite, and C nanocrystals. According to Moreno [23], Fe nanoparticles are generated mechanically by frictional wear, especially through the sliding of two metallic surfaces, followed by oxidation, while others suggested their generation via condensation of Fe vapor [18,24,30,61,62]. Magnetite crystals have octahedral and rhombic dodecahedral morphologies, whereas maghemite nanoparticles show an elongated cuboctahedral morphology [59]. Table 5 shows the chemical compositions of PM in Figure 13. The PM contained Fe and O (Table 5). The elemental ratios of particles $A$ and $B$ were similar, while particle $C$ presented comprised $71.32 \%$ Fe and $16.33 \%$ O. $\mathrm{C}$ was excluded due to the use of a TEM grid composed of $\mathrm{Cu}$ and $\mathrm{C}$. However, concentric $\mathrm{C}$ nanocrystals were detected in particle A (Figure 13). 

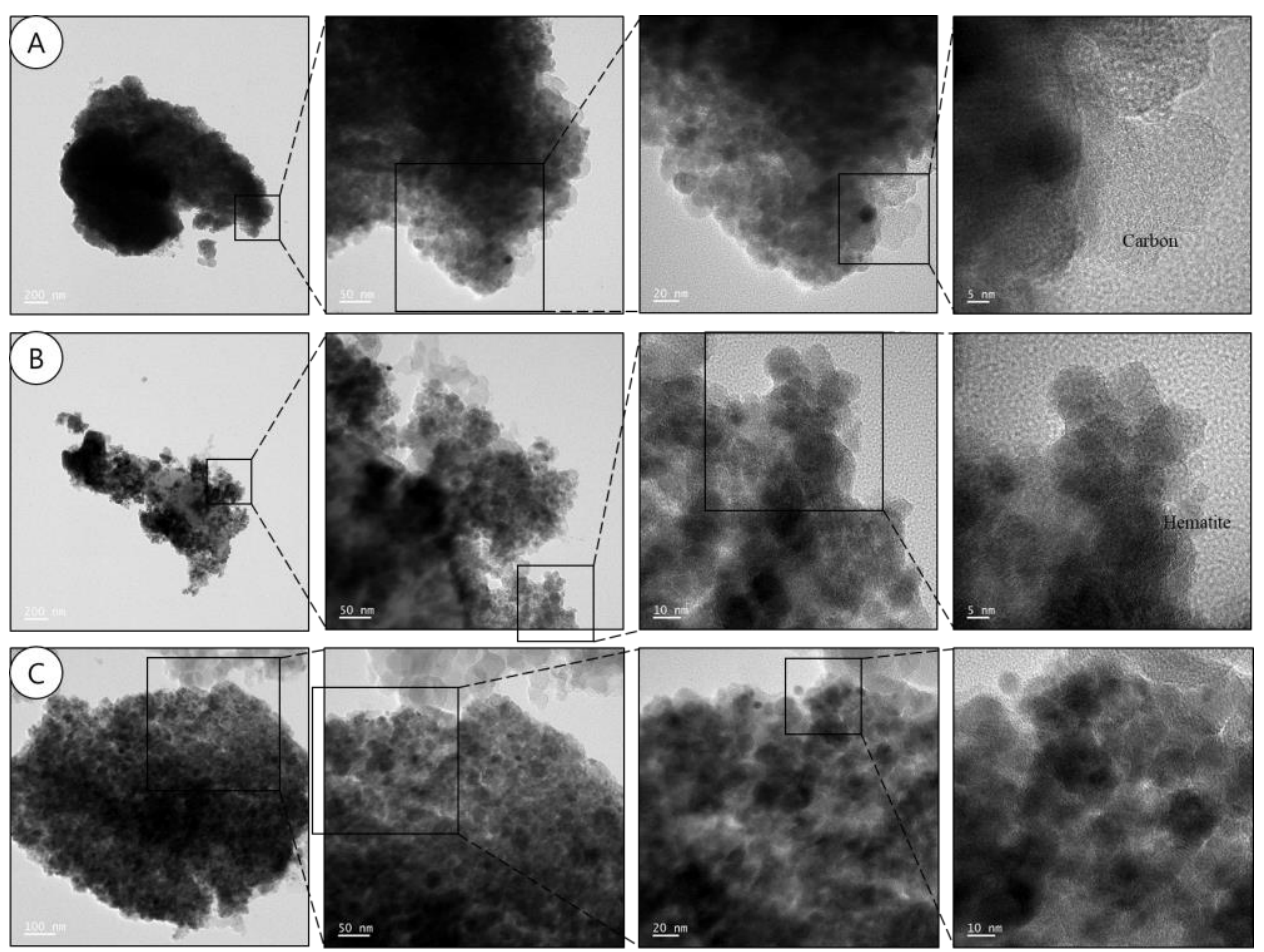

Figure 13. Morphology of PM in subway tunnels according to size at the S station.

Table 5. Chemical compositions * of three samples of PM in Figure 13 (unit, \%).

\begin{tabular}{cccc}
\hline Element & A & B & C \\
\hline Iron (Fe) & 43.98 & 43.94 & 71.32 \\
Oxygen (O) & 40.40 & 40.58 & 16.33 \\
Silicon (Si) & 6.59 & 6.59 & 3.71 \\
Magnesium (Mg) & 0.34 & 0.34 & 1.42 \\
Aluminum (Al) & 1.18 & 1.17 & 1.76 \\
Calcium (Ca) & 1.77 & 1.76 & \\
Sodium (Na) & 2.80 & 2.79 & \\
Phosphorus (P) & 0.68 & 0.68 & \\
Sulfur (S) & 0.47 & 0.47 & \\
Chlorine (Cl) & 0.54 & 0.54 & \\
Potassium (K) & 1.14 & 1.14 & \\
Titanium (Ti) & 0.12 & & \\
Zirconium (Zr) & & & \\
Sum & 100.00 & 100.00 & 100.00 \\
\hline
\end{tabular}

* $\mathrm{Cu}$ and $\mathrm{C}$ were excluded due to the use of a $\mathrm{Cu}-\mathrm{C}$ TEM grid.

\section{Conclusions}

In summary, Fe was the most abundant element in the subway tunnels, accounting for higher proportions of PM; Fe was detected in PM with diameters $>94 \mathrm{~nm}$, and was observed as mottling of clusters in rounded ferruginous nanocrystals with a few nanometers. Fe was present mostly as iron oxides, which were emitted from the wheel-rail-brake interface. Copper particles were 96-150 nm in diameter and were likely emitted via catenary wire arc discharges. The carbonaceous components of PM in subway tunnels originate from diesel PM emitted by the diesel motor car operated to maintain the tunnel. Organic material was transported from the outdoor air through the ventilation system and also originated from the pantograph carbon strip-catenary wire interface. Ca and $\mathrm{Si}$ in the subway tunnel, present as calcium carbonate $\left(\mathrm{CaCO}_{3}\right)$ and quartz $\left(\mathrm{SiO}_{2}\right)$, were detected in $\mathrm{PM}$ with diameters $>380 \mathrm{~nm}$. Calcium carbonate $\left(\mathrm{CaCO}_{3}\right)$ is a major component of cement, and quartz is the second most abundant mineral in continental crust. 
In the near future, our research team will conduct measurements at three locations (outdoors, platform, and tunnel) to identify PM exposure to passengers for each location.

These findings suggest that the majority of nano- and micro-PM in the subway tunnel in Seoul, South Korea is generated due to the operation of the subway. Our results can be used to improve the indoor air quality (IAQ) in subway tunnels and to prevent the generation of PM due to subway operation.

Author Contributions: D.P. and T.K. planned the study and contributed the main ideas; Y.L. and J.S.C. obtained and analyzed the data. Y.L. and Y.-C.L. were principally responsible for the writing of the manuscript; Y.-C.L. and D.P. commented on and revised the manuscript.

Funding: This work was supported by a research grant for the Railway Technology Research Project from the Ministry of Land, Infrastructure, and Transport, Republic of Korea (18RTRP-B082486-05). This research received no external funding.

Conflicts of Interest: The authors declare that they have no competing interests.

\section{References}

1. Pan, S.; Fan, L.; Liu, J.P.; Xie, J.C.; Sun, Y.Y.; Cui, N.; Zhang, L.L.; Zheng, B.Y. A review of the piston effect in subway stations. Adv. Mech. Eng. 2013, 5. [CrossRef]

2. Lee, Y.; Choi, K.; Jung, W.; Versoza, M.E.; Barabad, M.L.M.; Kim, T.; Park, D. Generation characteristics of nanoparticles emitted from subways in operation. Aerosol Air Qual. Res. 2018, 18, 2230-2239. [CrossRef]

3. Abbasi, S.; Wahlstrom, J.; Olander, L.; Larsson, C.; Olofsson, U.; Sellgren, U. A study of airborne wear particles generated from organic railway brake pads and brake discs. Wear 2011, 273, 93-99. [CrossRef]

4. Arias-Cuevas, O.; Li, Z.; Lewis, R.; Gallardo-Hernandez, E.A. Rolling-sliding laboratory tests of friction modifiers in dry and wet wheel-rail contacts. Wear 2010, 268, 543-551. [CrossRef]

5. Olofsson, U. A study of airborne wear particles generated from the train traffic-block braking simulation in a pin-on-disc machine. Wear 2011, 271, 86-91. [CrossRef]

6. Xu, B.; Hao, J. Air quality inside subway metro indoor environment worldwide: A review. Environ. Int. 2017, 107, 33-46. [CrossRef] [PubMed]

7. World Health Organization. Review of Evidence on Health Aspects of Air Pollution—REVIHAAP Project: Technical Report; WHO: Copenhagen, Denmark, 2013.

8. He, G.; Fan, M.; Zhou, M. The effect of air pollution on mortality in China: Evidence from the 2008 Beijing Olympic Games. J. Environ. Econ. Manag. 2016, 79, 18-39. [CrossRef]

9. Beelen, R.; Hoek, G.; van den Brandt, P.A.; Goldbohm, R.A.; Fischer, P.; Schouten, L.J.; Jerrett, M.; Hughes, E.; Armstrong, B.; Brunekreef, B. Long-term effects of traffic-related air pollution on mortality in a Dutch cohort (NLCS-AIR study). Environ. Health Perspect. 2008, 116, 196-202. [CrossRef] [PubMed]

10. Nieuwenhuijsen, M.J. Exposure Assessment in Occupational and Environmental Epidemiology; Oxford University Press: Oxford, UK, 2003.

11. Karlsson, H.L.; Nilsson, L.; Moller, L. Subway particles are more genotoxic than street particles and induce oxidative stress in cultured human lung cells. Chem. Res. Toxicol. 2005, 18, 19-23. [CrossRef] [PubMed]

12. Karlsson, H.L.; Ljungman, A.G.; Lindbom, J.; Moller, L. Comparison of genotoxic and inflammatory effects of particles generated by wood combustion, a road simulator and collected from street and subway. Toxicol. Lett. 2006, 165, 203-211. [CrossRef] [PubMed]

13. Maher, B.A.; Ahmed, I.A.M.; Karloukovski, V.; MacLaren, D.A.; Foulds, P.G.; Allsop, D.; Mann, D.M.A.; Torres-Jardon, R.; Calderon-Garciduenas, L. Magnetite pollution nanoparticles in the human brain. Proc. Natl. Acad. Sci. USA 2016, 113, 10797-10801. [CrossRef] [PubMed]

14. Chung, Y.W.; Kang, S.J.; Matsubayashi, T.; Sawada, Y.; Ueda, M. The effectiveness of platform screen doors for the prevention of subway suicides in South Korea. J. Affect. Disord. 2016, 194, 80-83. [CrossRef] [PubMed]

15. Kim, K.H.; Ho, D.X.; Jeon, J.S.; Kim, J.C. A noticeable shift in particulate matter levels after platform screen door installation in a Korean subway station. Atmos. Environ. 2012, 49, 219-223. [CrossRef]

16. Park, D.; Lee, T.; Hwang, D.; Jung, W.; Lee, Y.; Cho, K.; Kim, D.; Lee, K. Identification of the sources of $\mathrm{PM}_{10}$ in a subway tunnel using positive matrix factorization. Air Waste Manag. Assoc. 2014, 64, 1361-1368. [CrossRef] 
17. Querol, X.; Moreno, T.; Karanasiou, A.; Reche, C.; Alastuey, A.; Viana, M.; Font, O.; Gil, J.; de Miguel, E.; Capdevila, M. Variability of levels and composition of $\mathrm{PM}_{10}$ and $\mathrm{PM}_{2.5}$ in the Barcelona metro system. Atmos. Chem. Phys. 2012, 12, 5055-5076. [CrossRef]

18. Namgung, H.G.; Kim, J.B.; Woo, S.H.; Park, S.; Kim, M.; Kim, M.S.; Bae, G.N.; Park, D.; Kwon, S.B. Generation of nanoparticles from friction between railway brake disks and pads. Environ. Sci. Technol. 2016, 50, 3453-3461. [CrossRef] [PubMed]

19. Woo, S.H.; Kim, J.B.; Bae, G.N.; Hwang, M.S.; Tahk, G.H.; Yoon, H.H.; Yook, S.J. Investigation of diurnal pattern of generation and resuspension of particles induced by moving subway trains in an underground tunnel. Aerosol Air Qual. Res. 2018, 18, 2240-2252. [CrossRef]

20. Midander, K.; Elihn, K.; Wallen, A.; Belova, L.; Karlsson, A.K.B.; Wallinder, I.O. Characterisation of nanoand micron-sized airborne and collected subway particles, a multi-analytical approach. Sci. Total Environ. 2012, 427, 390-400. [CrossRef] [PubMed]

21. Jung, H.J.; Kim, B.; Ryu, J.; Maskey, S.; Kim, J.C.; Sohn, J.; Ro, C.U. Source identification of particulate matter collected at underground subway stations in Seoul, Korea using quantitative single-particle analysis. Atmos. Environ. 2010, 44, 2287-2293. [CrossRef]

22. Guo, L.; Hu, Y.J.; Hu, Q.Q.; Lin, J.; Li, C.L.; Chen, J.M.; Li, L.N.; Fu, H.B. Characteristics and chemical compositions of particulate matter collected at the selected metro stations of Shanghai, China. Sci. Total Environ. 2014, 496, 443-452. [CrossRef] [PubMed]

23. Moreno, T.; Martins, V.; Querol, X.; Jones, T.; BeruBe, K.; Minguillon, M.C.; Amato, F.; Capdevila, M.; de Miguel, E.; Centelles, S.; et al. A new look at inhalable metalliferous airborne particles on rail subway platforms. Sci. Total Environ. 2015, 505, 367-375. [CrossRef] [PubMed]

24. Jung, H.J.; Kim, B.; Malek, M.A.; Koo, Y.S.; Jung, J.N.; Son, Y.S.; Kim, J.C.; Kim, H.; Ro, C.U. Chemical speciation of size-segregated floor dusts and airborne magnetic particles collected at underground subway stations in Seoul, Korea. J. Hazard. Mater. 2012, 213, 331-340. [CrossRef] [PubMed]

25. Baldwin, A.C. Heterogeneous reactions of sulfur dioxide with carbonaceous particles. Int. J. Chem. Kinet. 1982, 14, 269-277. [CrossRef]

26. Ibusuki, T.; Barnes, H.M. Manganese(II) catalyzed sulfur dioxide oxidation in aqueous solution at environmental concentrations. Atmos. Environ. (1967) 1984, 18, 145-151. [CrossRef]

27. Sinha, A.; Bhattacharya, J. Environmental Kuznets curve estimation for $\mathrm{NO}_{2}$ emission: A case of Indian cities. Ecol. Indic. 2016, 67, 1-11. [CrossRef]

28. Krachler, M.; Mohl, C.; Emons, H.; Shotyk, W. Atmospheric deposition of V, Cr, and Ni since the late glacial: Effects of climatic cycles, human impacts, and comparison with crustal abundances. Environ. Sci. Technol. 2003, 37, 2658-2667. [CrossRef] [PubMed]

29. Lee, Y.; Lee, K.B.; Kim, J.S.; Park, D.; Kim, S.D. Study on the estimation of configuration ratio of ion compound with carbonate in subway. J. Odor. Indoor Environ. 2016, 15, 154-163. [CrossRef]

30. Loxham, M.; Cooper, M.J.; Gerlofs-Nijland, M.E.; Cassee, F.R.; Davies, D.E.; Palmer, M.R.; Teagle, D.A.H. Physicochemical characterization of airborne particulate matter at a mainline underground railway station. Environ. Sci. Technol. 2013, 47, 3614-3622. [CrossRef] [PubMed]

31. Park, D.; Oh, M.; Yoon, Y.; Park, E.; Lee, K. Source identification of $\mathrm{PM}_{10}$ pollution in subway passenger cabins using positive matrix factorization. Atmos. Environ. 2012, 49, 180-185. [CrossRef]

32. Martins, V.; Moreno, T.; Mendes, L.; Eleftheriadis, K.; Diapouli, E.; Alves, C.A.; Duarte, M.; de Miguel, E.; Capdevila, M.; Querol, X.; et al. Factors controlling air quality in different European subway systems. Environ. Res. 2016, 146, 35-46. [CrossRef] [PubMed]

33. Birch, M.E.; Cary, R.A. Elemental carbon-based method for monitoring occupational exposures to particulate diesel exhaust. Aerosol Sci. Technol. 1996, 25, 221-241. [CrossRef]

34. Jankowski, N.; Schmidl, C.; Marr, I.L.; Bauer, H.; Puxbaum, H. Comparison of methods for the quantification of carbonate carbon in atmospheric $\mathrm{PM}_{10}$ aerosol samples. Atmos. Environ. 2008, 42, 8055-8064. [CrossRef]

35. Krzyzanowski, M.; Cohen, A. Update of WHO air quality guidelines. Air Qual. Atmos. Health 2008, 1, 7-13. [CrossRef]

36. Yang, H.J.; Chen, G.X.; Gao, G.Q.; Wu, G.N.; Zhang, W.H. Experimental research on the friction and wear properties of a contact strip of a pantograph-catenary system at the sliding speed of $350 \mathrm{~km} / \mathrm{h}$ with electric current. Wear 2015, 332, 949-955. [CrossRef] 
37. Moreno, T.; Reche, C.; Minguillon, M.C.; Capdevila, M.; de Miguel, E.; Querol, X. The effect of ventilation protocols on airborne particulate matter in subway systems. Sci. Total Environ. 2017, 584-585, 1317-1323. [CrossRef] [PubMed]

38. Cheng, Y.H.; Lin, Y.L.; Liu, C.C. Levels of $\mathrm{PM}_{10}$ and $\mathrm{PM}_{2.5}$ in Taipei rapid transit system. Atmos. Environ. 2008, 42, 7242-7249. [CrossRef]

39. Lee, Y.; Jeong, W.; Choi, K.; Kim, T.; Park, D. Estimation of particulate matters in subway tunnels using a kriging method. J. Odor. Indoor Environ. 2016, 15, 126-133. [CrossRef]

40. Johansson, C.; Johansson, P.A. Particulate matter in the underground of Stockholm. Atmos. Environ. 2003, 37, 3-9. [CrossRef]

41. Mugica-Álvarez, V.; Figueroa-Lara, J.; Romero-Romo, M.; Sepúlveda-Sánchez, J.; López-Moreno, T. Concentrations and properties of airborne particles in the Mexico City subway system. Atmos. Environ. 2012, 49, 284-293. [CrossRef]

42. Martins, V.; Moreno, T.; Minguillon, M.C.; van Drooge, B.L.; Reche, C.; Amato, F.; de Miguel, E.; Capdevila, M.; Centelles, S.; Querol, X. Origin of inorganic and organic components of $\mathrm{PM}_{2.5}$ in subway stations of Barcelona, Spain. Environ. Pollut. 2016, 208, 125-136. [CrossRef] [PubMed]

43. Chow, J.C.; Watson, J.G.; Crow, D.; Lowenthal, D.H.; Merrifield, T. Comparison of IMPROVE and NIOSH carbon measurements. Aerosol Sci. Technol. 2001, 34, 23-34. [CrossRef]

44. Zhang, C.M.; Song, W.; Zhang, X.C.; Li, R.; Zhao, S.J.; Fan, C.M. Synthesis, characterization and evaluation of resin-based carbon spheres modified by oxygen functional groups for gaseous elemental mercury capture. J. Mater. Sci. 2018, 53, 9429-9448. [CrossRef]

45. Hering, S.; Cass, G. The Magnitude of bias in the measurement of $\mathrm{PM}_{2.5}$ arising from volatilization of particulate nitrate from teflon filters. J. Air Waste Manag. Assoc. 1999, 49, 725-733. [CrossRef] [PubMed]

46. Namgung, H.-G.; Kim, J.B.; Kim, M.-S.; Kim, M.; Park, S.; Woo, S.-H.; Bae, G.-N.; Park, D.; Kwon, S.-B. Size distribution analysis of airborne wear particles released by subway brake system. Wear 2017, 372-373, 169-176. [CrossRef]

47. Minguillon, M.C.; Reche, C.; Martins, V.; Amato, F.; de Miguel, E.; Capdevila, M.; Centelles, S.; Querol, X.; Moreno, T. Aerosol sources in subway environments. Environ. Res. 2018, 167, 314-328. [CrossRef] [PubMed]

48. Chillrud, S.N.; Epstein, D.; Ross, J.M.; Sax, S.N.; Pederson, D.; Spengler, J.D.; Kinney, P.L. Elevated airborne exposures of teenagers to manganese, chromium, and iron from steel dust and New York City's subway system. Environ. Sci. Technol. 2004, 38, 732-737. [CrossRef] [PubMed]

49. Zhang, W.G.; Jiang, H.M.; Dong, C.Y.; Yan, Q.; Yu, L.Z.; Yu, Y. Magnetic and geochemical characterization of iron pollution in subway dusts in Shanghai, China. Geochem. Geophys. Geosyst. 2011, 12. [CrossRef]

50. Wang, J.; Zhao, L.; Zhu, D.; Gao, H.O.; Xie, Y.; Li, H.; Xu, X.; Wang, H. Characteristics of particulate matter (PM) concentrations influenced by piston wind and train door opening in the Shanghai subway system. Transp. Res. D 2016, 47, 77-88. [CrossRef]

51. Salma, I.; Weidinger, T.; Maenhaut, W. Time-resolved mass concentration, composition and sources of aerosol particles in a metropolitan underground railway station. Atmos. Environ. 2007, 41, 8391-8405. [CrossRef]

52. Aarnio, P.; Yli-Tuomi, T.; Kousa, A.; Makela, T.; Hirsikko, A.; Hameri, K.; Raisanen, M.; Hillamo, R.; Koskentalo, T.; Jantunen, M. The concentrations and composition of and exposure to fine particles (PM2.5) in the Helsinki subway system. Atmos. Environ. 2005, 39, 5059-5066. [CrossRef]

53. Bukowiecki, N.; Gehrig, R.; Hill, M.; Lienemann, P.; Zwicky, C.N.; Buchmann, B.; Weingartner, E.; Baltensperger, U. Iron, manganese and copper emitted by cargo and passenger trains in Zurich (Switzerland): Size-segregated mass concentrations in ambient air. Atmos. Environ. 2007, 41, 878-889. [CrossRef]

54. Hu, Y.; Chen, G.X.; Zhang, S.D.; Gao, G.Q.; Wu, G.N.; Zhang, W.H.; Zhou, Z.R. Comparative investigation into the friction and wear behaviours of a $\mathrm{Cu}-\mathrm{Ag}$ contact wire/carbon strip and a pure copper contact wire/carbon strip at high speeds. Wear 2017, 376, 1552-1557. [CrossRef]

55. Zhang, Y.Y.; Zhang, Y.Z.; Du, S.M.; Song, C.F.; Yang, Z.H.; Shangguan, B. Tribological properties of pure carbon strip affected by dynamic contact force during current-carrying sliding. Tribol. Int. 2018, 123, 256-265. [CrossRef]

56. Ma, C.-J.; Lee, K.-B.; Kim, S.-D.; Sera, K. Chemical properties and source profiles of particulate matter collected on an underground subway platform. Asian J. Atmos. Environ. 2015, 9, 165-172. [CrossRef]

57. Karlsson, H.L.; Gustafsson, J.; Cronholm, P.; Moller, L. Size-dependent toxicity of metal oxide particles-A comparison between nano- and micrometer size. Toxicol. Lett. 2009, 188, 112-118. [CrossRef] [PubMed] 
58. Isozaki, H.; Oosawa, J.; Kawano, Y.; Hirasawa, R.; Kubota, S.; Konishi, S. Measures against electrolytic rail corrosion in Tokyo Metro Subway Tunnels. Procedia Eng. 2016, 165, 583-592. [CrossRef]

59. Guo, H.B.; Barnard, A.S. Naturally occurring iron oxide nanoparticles: Morphology, surface chemistry and environmental stability. J. Mater. Chem. A 2013, 1, 27-42. [CrossRef]

60. Choi, S.I.; Feng, J.; Kim, S.B.; Jo, Y.M. Magnetization of metal mesh for fine dust capture. Aerosol Air Qual. Res. 2018, 18, 1932-1943. [CrossRef]

61. Salma, I.; Posfai, M.; Kovacs, K.; Kuzmann, E.; Homonnay, Z.; Posta, J. Properties and sources of individual particles and some chemical species in the aerosol of a metropolitan underground railway station. Atmos. Environ. 2009, 43, 3460-3466. [CrossRef]

62. Kang, S.; Hwang, H.; Park, Y.; Kim, H.; Ro, C.U. Chemical compositions of subway particles in Seoul, Korea determined by a quantitative single particle analysis. Environ. Sci. Technol. 2008, 42, 9051-9057. [CrossRef] [PubMed]

(c) (

(C) 2018 by the authors. Licensee MDPI, Basel, Switzerland. This article is an open access article distributed under the terms and conditions of the Creative Commons Attribution (CC BY) license (http://creativecommons.org/licenses/by/4.0/). 